were seldom employed, owing to the extensive farming methods needed for success. After the 1960s the Cheetah population began to increase, probably due to the reduction in the numbers of large predators, the 'development' of water, and the resident animal wildlife populations.

Through the 1970s a wet cycle produced good grasses, and farmers stocked heavily - to two to three times the number of cattle that was recommended. In the late $1970 \mathrm{~s}$, when the first signs of the worst drought of the century appeared, the degenerative effects of a single species, cattle, on the land began to show. Grasses were disappearing, and bush was taking over. In many areas as much as $60 \%$ to $90 \%$ of the open grassland became heavy bush. Due to the effects of the drought on the grazing-land, many farmers resorted to catching the migratory game in order to protect their pastures for domestic stock, as the game had been 'claiming more than their fair share'. Between 1981 and 1983, the game populations in the country declined by $50 \%$, due to the effects of the drought and of gamecropping. During this time another problem also arose. The kudu (Strepticeros spp.) population, one of the Cheetah's main prey, declined by nearly $80 \%$ from a rabies virus, thus further reducing the Cheetahs' potential food-source.

During the wet years of the 1970 s, when prey was abundant, the Cheetah population had also increased. But in the 1980s, with grass cover low from the drought and wildlife numbers drastically reduced, the farmers began a war on the Cheetahs. Thus during the 1980 s as many as 700 to 800 Cheetahs per year were reported to have been killed or otherwise removed from the wild, and over a 10-years' period their numbers declined to half. From 1980 to 1991 , CITES reported that 6,782 Cheetahs were removed by Namibian farmers from the free-ranging Cheetah population.

\section{'Playtrees' and Trapping}

Cheetahs are primarily live-caught at what are commonly known in Namibia as 'playtrees'. These playtrees appear to be powerful focal points in the Cheetahs' range. They tend to be trees with sloping trunks (Fig. 1) which the Cheetah can easily run up, with large horizontal limbs from which the Cheetah can observe its surroundings. The animals leave their excreta on the limbs and urine on the trunk as markers. Three species of trees have been identified as used for playtrees, but the Cheetahs primarily use large Camel-thorn Trees (Acacia erioloba), the others being Shepherd's Tree (Boscia albitrunca) and Bastard Umbrella-thorn Tree (Acacia luederitzii).

Namibian Cheetahs appear to be unique in their use of playtrees. Not all farms have playtrees, and we have now termed these as pass-through farms, as the Cheetahs move quickly on their way to the next playtree. Some favoured farms have several playtrees, others just one. The live- traps, set at these trees, are two-metres-long wire cages with drop-doors at either end and a trigger in the middle. The trap is placed near the playtree, and a thorn-bush 'boma' makes the trap the only passage to the tree. The Cheetah's urge to get to the tree is so strong that it will readly use the trap as a passage and walk in, thus triggering the doors. When one Cheetah has been caught, it is held in a holding cage within the boma, and its vocalizations will attract other Cheetahs which in turn will be caught ( $c f$. Fig. 1).

The majority of this catching is indiscriminate, as the livestock-killing 'problem' animal is not singled out. In each region, there are certain farmers who catch continuously by leaving their traps open all the time. The survey information so far gathered suggests that this type of continuous, indiscriminate catching opens up territories, thus creating a vacuum and drawing in more Cheetahs than would normally be in the area, which in turn increases the farmer's potential problems. Ongoing research will shed further light on the full significance of the playtree. For example, does scent-marking the playtree affect the social stability of a Cheetah population in a specific area by altering one individual's proximity to another, and does this assist with avoidance and/or attraction?

\section{Needs for Survival}

For the Cheetah to survive, it must have a habitat and a prey-base. These essential elements can only be maintained through a holistic approach on the farmlands which incorporates land-use, livestock, and wildlife. We need to work towards a balance between the economic needs of the people and the survival of the species. The long-term goal of CCF is to develop a conservancy for Cheetahs on Namibia's commercial farmlands in cooperation with the farmers and the local human communities. Conservation of this last large stronghold for Cheetahs will determine whether the species will survive for future generations.

We believe that the Cheetah deserves a place on this Earth. Cheetahs are only one of the estimated 33 million species of biota living on our planet. Does it really matter if the Cheetah becomes extinct? It is tempting to think that the loss of only one species will not matter or at least will not affect us. But we must remember that all things on Earth are to some extent connected, and that Cheetahs are an integral part of the earthly superecocomplex, which comprises the main, central part of The Biosphere.

\section{LAURIE MARKER-KRAUS \& \\ DANIEL KRAUS \\ Cheetah Conservation Fund PO Box 247 \\ Windhoek, Namibia.}

\title{
The Natural Hazards Research and Applications Information Center
}

$T^{1}$ he Natural Hazards Research and Applications Information Center is a national clearinghouse for data relating to the economic loss, social disruption, and human response, associated with natural disasters and related technological risks. Creation of the Center was recommended following an interdisciplinary research project led by the celebrated geographer Gilbert F. White to assess the status of hazards research and applications in the US.* White founded the Center in 1975 and served as its Director until 1984 and again from 1991-1993. Housed within the Program on Environment and Behavior of the Institute of Behavioral Science at the University of Colorado in Boulder, the Center is now in its 20th year of existence and is financed by a consortium of seven federal agencies (National Science Foundation, National Oceanic and Atmospheric Administration, Federal Emergency Management Agency, US Army Corps of Engineers, US Environmental Protection Agency, National Institute of Mental Health, and US Geological Survey) and the Insurance Institute for Property Loss Reduction. The main 
goal of the Center is to strengthen communication between researchers and the individuals, organizations, and agencies, that are responsible for reducing losses from disasters.

The Center carries out its work in four major areas.

\section{1) Information Dissemination Program}

The information dissemination programme includes a newsletter, the Natural Hazards Observer; the publication of monographs, working papers, bibliographies, and other special publications; and operation of an electronic newsletter/network known as Disaster Research.

The 20-24 pages' Observer carries current information on hazards research and policy to over 13,000 subscribers in the US and abroad, six times a year. Domestic subscriptions are free; international subscriptions are $\$ 15$ per year. It provides readers with briefings on current research, new publications, congressional activities, agency programs, and upcoming conferences. The Observer also offers a forum for key hazards-players to express opinions and generate new ideas through the 'On the Line' column, and features lead articles in the 'Invited Comment' section. ${ }^{\dagger}$

The Center's other publications range from full-length research studies (monographs) to research-in-progress or article-length discussions of a specific problem (working papers, bibliographies, quick-response research reports, and other special publications). Thousands of copies of such items are distributed annually. They are designed to provide information to a wide range of readers - particularly practitioners - and, as such, they are carefully edited and produced in non-technical language. ${ }^{\dagger}$

Since 1989, the Center has managed an electronic newsletter known as Disaster Research (DR). The newsletter is operated via the Internet, but is available on a variety of other networks and bulletin boards around the country and globe. DR is mailed electronically every twothree weeks to more than 900 subscribers on five continents. It serves as an informal communication tool among persons who are interested in hazards research and disaster management.

\section{2) Annual Workshop}

To strengthen the link between the research and applications communities, the Natural Hazards Center convenes a workshop each summer to bring these groups together - to establish contacts and share hazard-related problems as well as ideas for their solution. The workshop draws about 300 attendees each year and addresses hazards' topics of current interest. In 1994, featured keynote speakers included James Lee Witt, Director of the Federal Emergency Management Agency, and Olavi Elo, Director of the UN's International Decade for Natural Disaster Reduction Secretariat. Plenary sessions focused on cultural diversity and disaster management, as well as

* Cf. Gilbert F. White \& J. Eugene Haas, Assessment of Research on Natural Hazards, the MIT Areas, Cambridge, Massachusetts, USA: 487 pp., 1975.

† The Natural Hazards Observer, now in its nineteenth volume, is habitually enlivened by able cartoons of droll figures that give it memorable character. - Ed. on policy issues emerging from the 1993 Midwest floods and the 1994 Northridge 'quake.

\section{3) Library Research Services Program}

At the heart of the Center is its library services program, which involves maintaining a large library on natural hazards and responding to requests for information and referrals.

The Natural Hazards Library is a resource containing more than 14,000 books, articles, reports, journals, and other documents, and it forms the core of the Center's clearinghouse activities. The holdings are included in a computerized, bibliographic database known as HAZBIB (about one-third of which are annotated) that is searchable by Author, title, key word, or full text. New additions to HAZBIB are made at a rate of about 250 items per year. Special computerized databases on meteorological hazards and floodplain management are also maintained in the library. The latter has been developed in collaboration with the Association of State Floodplain Managers.

With this Library resource, the Center staff responds to requests for information from federal, state, and local, officials, researchers, members of private and non-profit organizations, and others. The requests come mainly from people who are interested in knowing how to apply research results in practical settings in order to reduce damages from hazards. The Center plans to make this database available electronically within the next few years, enabling people to conduct their own searches for information. Whereas our interests are primarily North American (including Canada), our services have long been available to foreign correspondents for information and advice, and it is hoped to make them world-wide in due course.

\section{4) Research Program}

The Center's research programme is twofold. It includes an in-house research effort which currently is focusing on conducting an assessment of the status of hazards research and applications in the US. The project is expected to identify a set of research priorities for the hazards field in the future that will place natural hazards in a broader environmental context.

The Center's Quick Response programme provides a mechanism to support social scientists travelling to disaster sites to analyse situations in their post-impact period. Valuable data that might otherwise be lost are gathered, and later developed into reports offering policy options.

Persons interested in learning more about the Center or assessing its services should contact the undersigned.

DENNIS S. MILETI, Director
Natural Hazards Research
and Applications Information Center
University of Colorado
Campus Box 482
Boulder
Colorado 80309-0482,USA.
Tel. (303) 4926818
Fax (303) 4922151
Internet: Hazctr@Colorado. EDU

